\title{
IN LABORATORY GENERATION AND MATURATION OF HUMAN MONOCYTE-DERIVED DENDRITIC CELLS FOR CANCER IMMUNOTHERAPY
}

\author{
KANCHAN K. MISHRA ${ }^{*}$, SUMIT BHARADVA ${ }^{1}$, MEGHNAD G. JOSHI², ARVIND GULBAKE ${ }^{2}$
}

1Surat Raktadan Kendra and Research Centre, (Regional Blood Transfusion and Research Centre), (NABH Accredited and SIROs Recognition from DSIR, $1^{\text {st }}$ Floor, Khatodara Health Centre, Khatodara 395002, Surat (Gujarat), India, ${ }^{2}$ Department of Stem Cells and Regenerative Medicine, Centre for Interdisciplinary Research, D. Y. Patil Education Society Institution Deemed to be University, Kolhapur, India

Email: kanchan008@gmail.com

Received: 3 Apr 2020, Revised and Accepted: 13 Aug 2020

\begin{abstract}
Dendritic cells (DCs) play a critical role in the regulation of adaptive immune responses, furthermore they act as a bridge between the innate and the adaptive immune systems they have been ideal candidates for cell-based immunotherapy of cancers and infections in humans. The first reported trial using DCs in 1995, since they have been used in trials all over the world for several of indications, including cancer and human immunodeficiency virus infection. Generally, for in vitro experiments or for DCs vaccination monocyte-derived dendritic cells (moDCs) were generated from purified monocytes that isolated from peripheral blood by density gradient centrifugation. A variety of methods can be used for enrichment of monocytes for generation of clinical-grade DCs. Herein we summarized up to date understanding of systems and inputs used in procedures to differentiate DCs from blood monocytes in vitro.
\end{abstract}

Keywords: Dendritic Cells, Monocyte-derived Dendritic Cells, Immunotherapy

(C) 2020 The Authors. Published by Innovare Academic Sciences Pvt Ltd. This is an open access article under the CC BY license (http://creativecommons.org/licenses/by/4.0/) DOI: http://dx.doi.org/10.22159/ijap.2020.v12s4.40104. Journal homepage: https://innovareacademics.in/journals/index.php/ijap

\section{INTRODUCTION}

For more than a century it has been hypothesized that the immune system can be redirected to target malignant cells and thus cure cancer $[1,2]$. In 1973 Steinman discovered a new type of immune cell, the dendritic cell (DCs) [3], which play an important role in the induction of specific immunity. DCs are sentinels of the immune system, as they are deployed throughout the body and monitor their surroundings for antigens and danger signals derived from pathogens or tissue damage. DCs have been clinically used for three decades, with more than 300 completed or ongoing registered clinical trials conducted to test their application for boosting anti-tumor immunity [4]. DCs are the most potent professional antigen-presenting cells (APC) and play critical roles in regulating the innate and adaptive immune responses [5].

In their immature state, DCs mainly reside in lymphoid and peripheral tissues where they recognize and capture antigens and become activated in the presence of foreign pathogens. This activation occurs following stimulation by exogenous danger signals via pattern recognition receptors (PRR) such as Toll-like receptors (TLR) $[6,7]$ and leads to DC migration to the draining lymph node and the presentation of the processed epitopes to $\mathrm{T}$ cells. During the T cell activation, DC engages the T-cell receptor (TCR), secrete specific cytokines and stimulate the immune responses toward $\mathrm{TH} 1, \mathrm{TH} 2$, or Tregs depending on the cytokine environment. Due to their proficiency at antigen crosspresentation (i.e., the presentation to both CD4+and CD8+T cells) DC have been used as vaccine platforms to induce anti-tumor cytotoxic T lymphocyte (CTL) CD8 immune responses [8, 9].

With DC vaccination, mature DCs loaded with tumor antigens exvivo are injected into cancer patients to induce tumor-specific effector T-cells that aim to recognize and eliminate cancer cells and induce immunological memory to control tumor growth [10]. In the majority of clinical DC vaccination trials conducted so far, DCs differentiated ex-vivo from monocytes or CD34+progenitors have been used, since naturally circulating DCs (nDCs) are present in the blood but only constitute about $1 \%$ of blood mononuclear cells. The most commonly used preparation involves the reinfusion of ex-vivo derived DC pulsed with tumor-associated antigens (TAAs) or tumor cell lysates and stimulated with a defined maturation cocktail. The gold standard maturation cocktail included the pro-inflammatory cytokines TNF- $\alpha$, IL-1 $\beta$, and IL- 6 in combination with prostaglandinE2 (PGE2) [11, 12]

While, DC-based vaccinations appeared promising after Sipuleucel-T (Provenge $®)$ approval in 2010, a DC-based immunotherapy for the treatment of advanced prostate cancer [13], however unfortunately, the vaccination against established malignancies has shown partial clinical benefit

Recently Indian government agency (CDSCO-Central Drugs Standard Control Organization) has approved in 2017 an autologous monocyte-derived and tumor lysate-pulsed mature DCbased vaccine (APCEDEN囚) for treatment of four cancer suggestions (prostate, ovarian, colo-rectal and non-small cell lung carcinoma) [14]. Furthermore, the efficacy profile of APCEDEN@ therapy demonstrated a survival benefit of $>100 \mathrm{~d}$ [14]. Various types of DC vaccines have been evaluated in clinical trials so far (table 1). The most commonly used preparation involves the reinfusion of ex-vivo derived DC pulsed with tumor-associated antigens (TAAs) or tumor cell lysates and stimulated with a defined maturation cocktail and clinical trial results demonstrated encouraging outcome along with safe and well-tolerated in patients with solid tumors [15]

We explored previous and recent years published papers in English indexed in Pubmed from 1967-2020, using key words like Cancer immunotherapy, Generation of DCs, Monocytes presence of a cytokine cocktail and growth factors, DC vaccination and Antigen loading/pulsing method. The papers quoted in the references of those articles were also explored. In this review, we have briefed the cellular aspects essential for Monocyte-derived dendritic cells efficacy, the selection of suitable culture medium, appropriate culture medium supplements, growth factors, and cytokines. We will also review the molecular markers used to characterize DCs by flow cytometry and antigen loading of moDCs. 
Table 1: Current encouraging clinical trials using personalized DC-based vaccines [15]

\begin{tabular}{|c|c|c|c|c|c|c|c|c|}
\hline \multicolumn{3}{|c|}{ NCT number } & \multirow{2}{*}{\begin{tabular}{|l|} 
Indication \\
Ovarian cancer
\end{tabular}} & \multirow{2}{*}{$\begin{array}{l}\text { Interventions } \\
\text { Ontak (anti-CD25) DC vaccine+ontak }\end{array}$} & \multirow{2}{*}{$\begin{array}{l}\text { Phase } \\
\text { Phase-2 }\end{array}$} & \multirow{2}{*}{$\begin{array}{l}\text { Enrolment } \\
36\end{array}$} & \multirow{2}{*}{$\begin{array}{l}\begin{array}{l}\text { Start } \\
\text { date }\end{array} \\
2008 \\
\end{array}$} & \multirow{2}{*}{$\begin{array}{l}\begin{array}{l}\text { Estimated } \\
\text { primary } \\
\text { completion } \\
\text { date }\end{array} \\
2018\end{array}$} \\
\hline Tumor & 1 & NCT00703105 & & & & & & \\
\hline Lysate & 2 & NCT01204684 & $\begin{array}{l}\text { Glioma Astrocytoma } \\
\text { Astro-oligodendroglioma } \\
\text { Glioblastoma }\end{array}$ & $\begin{array}{l}\text { Autologous tumor lysate-pulsed DC }+0.2 \% \\
\text { resiquimod DC vaccination+polyICLC }\end{array}$ & Phase-2 & 60 & 2010 & 2018 \\
\hline & 3 & NCT01635283 & $\begin{array}{l}\text { Newly diagnosed or } \\
\text { recurrent low-grade } \\
\text { glioma }\end{array}$ & Tumor lysate-pulsed autologous DC vaccine & Phase-2 & 18 & 2012 & 2019 \\
\hline & 4 & NCT01946373 & Malignant melanoma & $\begin{array}{l}\text { Cyclophosphamide Fludarabine T cells } \\
\text { Interleukin-2 DC vaccine }\end{array}$ & Phase-1 & 10 & 2013 & 2018 \\
\hline & 5 & NCT01973322 & $\begin{array}{l}\text { Malignant melanoma stage } \\
\text { III, Stage IV }\end{array}$ & $\begin{array}{l}\text { Arm 1: autologous DC loaded with autologous } \\
\text { tu lysate (DC vaccine)+RT Arm 2: DC } \\
\text { vaccine+IFN- } \alpha \text { Arm 3: both arm } 1 \text { and } 2+\text { RT } \\
\text { Arm 4: DC vaccine }\end{array}$ & Phase-2 & 24 & 2013 & 2019 \\
\hline & 6 & NCT01957956 & $\begin{array}{l}\text { Newly diagnosed } \\
\text { glioblastoma }\end{array}$ & $\begin{array}{l}\text { Tumor lysate-pulsed autologous dendritic cell } \\
\text { vaccine+temozolomide }\end{array}$ & $\begin{array}{l}\text { Early } \\
\text { phase-1 }\end{array}$ & 21 & 2013 & 2016 \\
\hline & 7 & NCT01808820 & $\begin{array}{l}\text { Malignant glioma } \\
\text { Glioblastoma }\end{array}$ & $\begin{array}{l}\text { Dendritic cell vaccine Tumor lysate Imiquimod } \\
\text { Leukapheresis }\end{array}$ & Phase-1 & 20 & 2013 & 2019 \\
\hline & 8 & NCT02496520 & $\begin{array}{l}\text { Advanced solid tumors, } \\
\text { sarcoma Central nervous } \\
\text { system tumor }\end{array}$ & $\begin{array}{l}\text { Dendritic cells Surgery as needed } \\
\text { Chemotherapy as needed Radiation: radiation } \\
\text { therapy as needed }\end{array}$ & $\begin{array}{l}\text { Phase } \\
1 \mid 2\end{array}$ & 10 & 2014 & 2018 \\
\hline & 9 & NCT01803152 & $\begin{array}{l}\text { Sarcoma Soft tissue } \\
\text { sarcoma Bone sarcoma }\end{array}$ & $\begin{array}{l}\text { Biological: dendritic cells vaccine Lysate of } \\
\text { tumor Gemcitabine Imiquimod Leukapheresis }\end{array}$ & Phase-1 & 56 & 2014 & 2019 \\
\hline & 10 & NCT02718391 & Malignant melanoma & DC pulsed with autologous tumor lysate & Phase-2 & 120 & 2015 & 2019 \\
\hline & 11 & NCT02301611 & Malignant melanoma & $\begin{array}{l}\text { Autologous Tumor Lysate (TL)+Yeast Cell Wall } \\
\text { Particles (YCWP)+Dendritic Cells (DC) } \\
\text { (TLPLDC Vaccine) Placebo }\end{array}$ & Phase- 2 & 120 & 2015 & 2019 \\
\hline & 12 & NCT02503150 & $\begin{array}{l}\text { Metastatic colorectal } \\
\text { cancer }\end{array}$ & $\begin{array}{l}\text { Antigen pulsed dendritic cells+chemotherapy } \\
\text { Chemotherapy }\end{array}$ & Phase-3 & 480 & 2015 & 2019 \\
\hline & 13 & NCT02678741 & Metastatic melanoma & $\begin{array}{l}\text { TLPLDC vaccine in addition to standard of care } \\
\text { checkpoint inhibitor of choice }\end{array}$ & $\begin{array}{l}\text { Phase } \\
1 \mid 2\end{array}$ & 45 & 2016 & 2019 \\
\hline & 14 & NCT03395587 & $\begin{array}{l}\text { Newly diagnosed } \\
\text { glioblastoma }\end{array}$ & $\begin{array}{l}\text { Autologous DC pulsed with autologous tumor } \\
\text { lysate }\end{array}$ & Phase-2 & 136 & 2018 & 2022 \\
\hline & 15 & NCT03360708 & Recurrent glioblastoma & $\begin{array}{l}\text { Cytokine-induced killer cells Tumor lysate- } \\
\text { pulsed autologous DC vaccine }\end{array}$ & $\begin{array}{l}\text { Early } \\
\text { phase-1 }\end{array}$ & 20 & 2018 & 2022 \\
\hline & 16 & NCT03014804 & Recurrent glioblastoma & $\begin{array}{l}\text { Autologous dendritic cells pulsed with tumor } \\
\text { lysate Nivolumab }\end{array}$ & Phase-2 & 30 & 2018 & 2020 \\
\hline $\begin{array}{l}\text { RNA } \\
\text { Peptide }\end{array}$ & 17 & NCT01983748 & Uveal melanoma & $\begin{array}{l}\text { Autologous DC loaded with autologous tumor } \\
\text { RNA }\end{array}$ & Phase-3 & 200 & 2014 & 2022 \\
\hline & 18 & NCT02775292 & $\begin{array}{l}\text { Adult solid neoplasm } \\
\text { Childhood solid neoplasm } \\
\text { Metastatic neoplasm }\end{array}$ & $\begin{array}{l}\text { Aldesleukin Cyclophosphamide Fludarabine } \\
\text { phosphate Nivolumab NY-ESO-1 reactive TCR } \\
\text { retroviral vector transduced autologous PBL } \\
\text { NY-ESO-1(157-165) peptide-pulsed autologous } \\
\text { DC vaccine }\end{array}$ & Phase-1 & 12 & 2017 & 2019 \\
\hline $\begin{array}{l}\text { Tumor } \\
\text { Neoantig }\end{array}$ & 19 & NCT01885702 & Colorectal cancer & Neoantigen-loaded DC vaccination & $\begin{array}{l}\text { Phase } \\
1 \mid 2\end{array}$ & 25 & 2010 & 2016 \\
\hline en & 20 & NCT03300843 & $\begin{array}{l}\text { Melanoma } \\
\text { Gastrointestinal Breast } \\
\text { Ovarian Pancreatic cancer }\end{array}$ & $\begin{array}{l}\text { DC vaccine loaded with neoantigen coding } \\
\text { peptide }\end{array}$ & Phase-2 & 86 & 2018 & 2027 \\
\hline
\end{tabular}

\section{Sources of monocytes}

It's very impressive for monocyte-derived dendritic cell culture is to select the monocyte source, since these cells are the preferred precursors for in vitro moDCs generation. One probability is to directly collect blood by venipuncture. The advantage of whole blood as a monocyte source is the freshness of the material. However, the drawback of using whole blood is the low yield of monocytes, since they represent only $6 \%$ of all peripheral blood cells, so using whole blood requires the processing of a large blood volume [16]. Processing a $450 \mathrm{ml}$ blood bag usually generates 30-80 $\mathrm{ml}$ of buffy coat with approximately $1 \times 10^{9}$ cells [17]

Second possible source is a leukopak. This is an enriched leukapheresis product consisting of a variety of blood cells including monocytes, lymphocytes, and erythrocytes. There are two types of leukopaks: one is collected from peripheral blood without any stimulation on the blood donor and the other are obtained from donors who were stimulated with G-CSF (granulocyte colony stimulating factor) to induce leukocyte production and trigger migration of stem cells from bone marrow into the bloodstream [18].

Although the production of leukopaks from such specific donors is not usual, this kind of product can be commercially provided under request. Commercial leukopaks generally contain $80-200 \mathrm{ml}$ of processed material with approximately $7 \times 10^{9}$ peripheral blood mononuclear cells (PBMC), [19] (more information available on: www. allcells. com/products/whole-tissue/leuko-pak). The effect of various DC vaccination parameters on immunological and clinical outcome of vaccination has been studied in numerous small phase I/II clinical trials in cancer patients. Most of these studies have been performed with moDCs, due to their easy differentiation protocol in vitro [20].

\section{Separation of monocytes from whole blood}

After consider the source of cells the next step in moDCs isolation and culture. In 1968, Boyum introduced a convenient and rapid separation using centrifugation through a Ficoll-sodium metrizoate solution [21]. This separation method takes advantage of cell density differences of the components in whole blood that, when centrifuged in the presence of a density gradient media, exhibits a unique migration pattern through the medium allowing distinct cell populations to be fractionated [22].

Following centrifugation above the FicollPaque layer, PBMCs form a layer of cells similar to a cloud, while the plasma is the uppermost layer in the tube. The PBMC layer includes B and T lymphocytes, monocytes, NK (Natural Killer) cells, and dendritic cells [23]. FicollPaque methodology is highly efficient and recovers around $95 \%$ of the mononuclear cells present in the original blood sample $[24,25]$. There is a very vital step during isolation of PBMCs from blood, one of them is pipetting and carefully layering of blood over density gradient solution into centrifuge tubes, and a second vital step is centrifugation acceleration and deceleration is very critical. 


\section{Isolation of monocytes from whole blood}

Since monocytes is the ability to adhere to inert surfaces like plastic, different from other cells present in the PBMC fraction. Monocytes isolation procedure take advantage of this characteristic usually seed PBMC cells in a plastic flask with the appropriate culture medium and allow adherence for $2 \mathrm{~h}$ in a humidified incubator. All monocytes will adhere to the culture flask while $\mathrm{B}$ and $\mathrm{T}$ lymphocytes, NK cells, and DCs will remain non-adherent and can be eliminated as floating cells [26].
Another distinct characteristic of monocytes is the only circulating blood cells to show high expression of CD14 on their membrane, this molecule is widely used as a biomarker for monocytes and as a target for their purification (fig. 1) [27]. It is worthy of note that the CD14 molecule belongs to the lipopolysaccharide (LPS) receptor complex. Recognition through this receptor is interpreted by the cell as a "danger signal" [28] capable of inducing a maturation process on immature DCs.
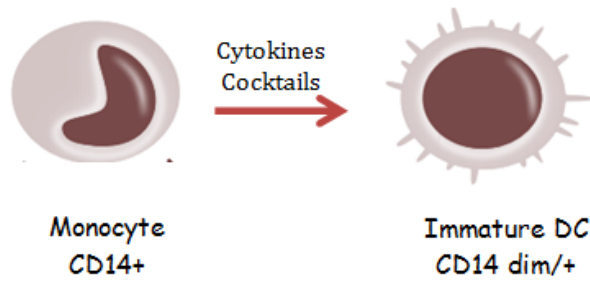

Immature $D C$ CD14 dim/+

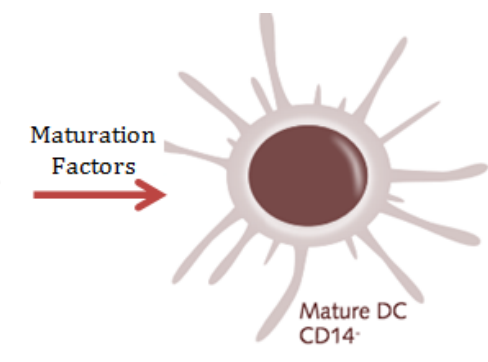

CD14.

Fig. 1: Generation and maturation of moDCs [27]

\section{Culture medium for monocyte-derived dendritic cell}

There are numerous different culture media described and used for moDCs [29]. However, it is essential to consider the general and specific objectives of the experiments, as well to take into consideration the cost of the different supplements to be used. If the main objective is for clinical purpose (therapeutic grade), utilizeonly Food and Drug Administration (FDA) approved culture medium like AIM-V (GIBCO, Catalog number: 087-0112DK). For research purposes, PromoCell, for example, offers three different medium types: DC Generation Medium (Catalog number: C-28050), DC Generation MediumDXF (Catalog number: C-28052), and Monocyte Attachment Medium (Catalog number: C-28051).

Another culture medium used to generate moDCs is RPMI-1640. It was developed by Moore and colleagues at the Roswell Park Memorial Institute, hence the acronym RPMI [30]. The RPMI-1640 composition is available and well established and there are several customized versions of RPMI, some of them lacking specific components, others already supplemented with certain growth factors or other molecules [22, 31].

Serum is a quite ubiquitous supplement in cell cultures. The final concentrations of serum used vary from $1-10 \%$. It is also feasible to use plasma or umbilical cord blood serum. Nevertheless, if the cells will not be used in clinical applications, fetal bovine serum (FBS) is the least expensive choice, and is also easier to obtain. Though cell culture procedures are performed in aseptic environments, however any biological contaminant can demolish the cell culture, therefore the use of antibiotics and antimycotics is at times required. The most frequent antibiotics used in cell cultures are penicillin-streptomycin for Gram-positive and Gram-negative bacteria whereas gentamicin against mycoplasmain culturing cells that are intended for clinical use, the FDA does not recommend the use of penicillin or $\beta$-lactams due to the possibility of severe hypersensitivity reactions [32]. A broadly used antifungal agent is amphotericin B. It acts against both fungi and yeasts. Generally, monocyte cultured in RPMI-1640 media supplemented with 1-10\% FBS, 2 mmol Glutamax, $100 \mu \mathrm{g} / \mathrm{ml}$ penicillin/streptomycin, $1 \%$ non-essential amino acids and $1 \%$ sodium pyruvate [31].

The time required to establish monocyte cell differentiation in vitro is quite variable. The most of the studies consider that the differentiation process from monocyte to immature DC is terminated in five days with an additional period of $48 \mathrm{~h}$ for maturation [33,34, and 35].

\section{Cytokines for the moDCs}

Sallusto and Lanzavecchia [36] are former to achieve in vitro moDCs generation with medium supplementation and through different cytokines, combined use of IL-4 and GM-CSF. In the subsequent years, numerous works characterized different protocols regarding the use of different cytokines in order to induce in vitro monocyte differentiation and maturation. It is important to know that different combinations of cytokines will generate moDCs with diverse characteristics and functions, thus we should decide the cytokines that good match the cause of the research work.

GM-CSF growth factor appears to down-regulate the expression of the macrophage colony-stimulating factor (M-CSF) receptor on monocytes, thus inhibiting M-CSF induced differentiation of monocytes into macrophages [37]. In the same way, IL-4 applies its actions in monocytes differentiation by inhibiting macrophage colony formation [38, 39]. The DC generated by this procedure, after seven days in culture, demonstrates a typical dendritic morphology.

Sanarico and his groups [40] explain different methodology for inducing differentiation of moDCs in vitro using GM-CSF, IL-4, and IL2. Another combination of cytokines was used to generate moDCs by Takahashi et al. [41]. A combination of GM-CSF and IL-7 gave rise to floating cells with characteristic DC morphology and a few adherent cells developed the appearance of Langerhans cell-like dendrites. Santini et al.[42], and Mohty et al. [43] two different groups used the combination of GM-CSF and IFN- $\alpha$ to produce moDCs in vitro. Moreover, in both cases, the DCs generated with GM-CSF and IFN- $\alpha$ showed a typical DC morphology. Iwamoto and co-workers used TNF$\alpha$ together with GM-CSF to initiate the differentiation of monocytes into DCs (called TNF-DC by the authors), [44].

\section{In vitro maturation of moDCs}

Generally in vivo, DC maturation is triggered by bacterium, virus, or other microorganism or tissue injury. To induce the DC maturation process in vitro it is necessary to give a stimulus that mimics a danger signal $[28,45]$. In vitro, this can be imitated by incubation with pathogen receptor agonists or a cocktail of proinflammatory cytokines.

Most common material used to mimic DC activation when provoked by bacteria is LPS, a characteristic component of the wall of Gramnegative bacteria [46, 47]. However, due to its possible toxicity, LPS is only used in research protocols.

Flagellin is another substance that mimics the danger signal triggered by the presence of Gram-negative and/or Gram-positive bacteria. Flagellin induced DC maturation results in the activation of the NF- $\mathrm{\kappa B}$ signaling pathway and cytokine production [48]. Imiquimod and Poly (I: C) also have been used as adjuvants in protocols to develop cancer vaccines [49]. Short synthetic single-stranded DNA molecules that contain unmethylated $\mathrm{CpG}$ dinucleotides (CpG) are also used as TLR9 agonists to activate iDCs [50]. 
Interleukins and several other molecules can simultaneously be used to induce DC maturation. A "maturation cocktail" canhave IL-6, IL$1 \beta$, TNF- $\alpha$, IFN- $\gamma$, and PGE2 [51]. This cocktail augments the proinflammatory effects of TNF- $\alpha$ by generating an inflammatory environment that induces DC maturation [45].

However, a cytokine cocktail consisting of tumor necrosis factor $(\mathrm{TNF} \alpha)$, interleukin (IL)-1 $\beta$, IL-6 and PGE2, or monocyteconditioned medium with TNF $\alpha$ and PGE2 are the most widely used methods for moDC maturation [51, 52].

Although whether this is the best cocktail to induce maturation, still it's controversial because PGE2 may confer immunosuppressive effects [53,54]. To further induce DC activation, mimicking viral infection, type-I interferons have been added to the cocktail [55]. Furthermore recently, utilize of Toll-like receptor (TLR) ligands [56, 57] or electroporation with mRNA-encoding proteins that induce DC maturation [58] has been investigated.

\section{The immunophenotyping of moDCs}

Dendritic cells are so called because of their characteristic cell surface projections that resemble the dendrites of neurons. DCs are a heterogeneous cell population in terms of locations, phenotypes, and immunological functions. Such plasticity DCs allows to differentially shape the immune response when presented with diverse pathogens. DCs, monocytes and macrophages usually comprise the mononuclear phagocyte system. An emerging theme is that components of this system are not as related as was presumed a decade ago. Currently Flow cytometry is frequently used to analyze lymphocyte subsets but synchronized detection of DCs and monocytes is hampered by the lack of a positive lineage marker.

Therefore because of the lack of DC specific markers, it is query whether DCs constitute a separate lineage of cells. The perplexity is related to results showing that DCs can be generated from mature peripheral blood Monocytes as well as from un separated CD34+progenitor cells when cultured in the presence of GM-CSF and TNF- $\alpha[59,60]$.

The success of the moDCs differentiation can be characterized by phenotype of the DCs. Thus farther expression of certain molecules is typically used to indicate successful moDCs differentiation and/or maturation. Because peripheral blood monocyte, is the main source for in vitro DC generation, expresses high levels of CD14 on its membrane, and moDCs lacks the expression of this same molecule.

Furthermore, to find out the success of the iDC maturation process, it is vital to monitor the increased expression of co-stimulatory molecules such as CD40, CD80, and CD86. These molecules are constitutively expressed at low levels in DCs, however, their expression considerably increased after induction of maturation by LPS $[61,62]$.

On the other hand, Human leukocyte antigen-II (HLA-II) molecule constitutively expressed at low levels in both monocytes and DCs. After a maturation stimulus, its expression on DCs is augmented. Therefore, like co-stimulatory molecules, HLA-II can be used as an indicator of the success of the iDC maturation process [63, 64].

Besides that, in blood monocytes, CD isoforms for example CD1a, CD1b, and CD1c (BDCA-1) can be upregulated on the cell surface by cytokine cocktails designed to drive DC differentiation in vitro [65].

Next potential markers are CD207 [66], and CD209 (DC-SIGN), which is expressed on plasmacytoid DCs (pDCs) and moDCs and is greatly expressed on DCs in mucosal tissues. The expression of this last marker is increased after LPS-mediated DC maturation induction [67].

\section{Antigen loading of moDCs}

Our immune system is able to differentiate between self, non-self and eradicate damaged cells. To evade elimination by immune responses, tumors, cancerous cells not only acquire the capability to prevent immune recognition, but also create an immunosuppressive environment and actively hijack immune cells to aid in tumor progression $[68,69]$. Reactivating the immune system to treat patients with cancer was proposed at the end of the nineteenth century and cancer immunotherapy has further developed ever since [70, 71]. DCs loaded ex-vivo with specific TAAs or whole tumor lysate to generate an immune response aiming for cancer-cell elimination and recently in vivo loading of DCs is being exploited [72, 73].

Thus, to induce a tumor-specific immune response, DCs should be loaded with tumor antigens. The most extensively used techniques for antigen loading of DCs vaccines are pulsing DCs with or tumor lysate, MHC-binding peptides of TAAs, corresponding long peptides or proteins, or TAA-encoding mRNA. All antigen-loading techniques have their own advantages and disadvantages and not any technique has proven to be superior to the others thus far. However recently, there is a great effort made in improving existing DC vaccines and developing new ones. Moreover, DCs loading together MHC class-I and class-II epitopes appears favourable for the quality of the induced immune response [74]. Various new approaches include genetically engineered DCs that express TAAs or display enhanced immunostimulatory properties or explore in vivo antigen loading of DCs with freshly released TAAs due to chemotherapy or immunogenic tumor-cell death [75-77].

\section{DISCUSSION}

A dendritic cell for immunotherapy using ex-vivo generated moDCs in patients with cancer was first explored over two decades ago [78]. A various clinical trial [79] has established the safety and ability of moDCs immunotherapy to induce anti-tumor responses [80, 81]. Therefore, based on the known difficulties of isolating and generating moDCs from human blood, here we provide and discussed comprehensive information for the generation of moDCs.

In order to study the biology of DCs, and their roles in immune responses, and their potential use for the treatment of certain diseases, and methods to generate mouse DCs in vitro have been well described by Shortman, [82]. DCs have unique features that have made them an ultimate choice for antitumor vaccines. They are considered as the most effective APC accountable for primarily sensitizing naive $\mathrm{T}$ cells to specific antigens [83]. DCs are 100-times more potent than APCs, B cells and monocytes, in inducing T-cell proliferation $[84,85]$. Furthermore, DCs play a central role in the establishment of immunologic memory [86]. In compare with monocytes and B cells, DCs are able to use soluble protein antigens to sensitize naive $\mathrm{T}$ cells in vitro [84]. Using these soluble proteins, DCs have successfully sensitized CD4+ [87] and CD8+T cells inducing antigen-specific cytotoxic $\mathrm{T}$ lymphocytes (CTLs) [88, 89]. This potential capacity gives developers of DC-based vaccines a wider range of potential antigen targets that can be effectively used to sensitize T cells. With respect to their use against cancer, the ability of DCs to prime T cells to attack tumor cells has been demonstrated in vitro [90] as well as in various animal models [91, 92]. Another, studies in 1990s, by Sallusto and Lanzavecchia, [36] confirmed that human monocytes differentiate into DCs in vitro by culturing with GM-CSF and IL-4.

Moreover, injection of moDCs and pulsed with exogenous antigens used to rapidly expands human $\mathrm{T}$ cell immunity [93]. Furthermore moDCs pulsed with certain TAAs can frequently expand CTLs and elicit regression even in advanced cancer [94]. The GM-CSF in vitro cultured DC is the most common DC type used in studies of mouse and human DC biology, and for immunotherapy using DC vaccines [82]. The differentiation of monocytes in vivo [95] and under mimicked physiological conditions [96] has previously been confirmed. In addition to playing a role in activating the immune system, DCs can also induce immune tolerance, which is a potential barrier to a successful vaccine strategy. Evidence has suggested that DCs that are not fully matured will be prone to inducing tolerance [97, 98].

\section{CONCLUSION}

The medical and scientific community established marvellous efforts in the understanding DCs and their precursors. As a result of such efforts, moDCs are presently used in clinical protocols for the treatment of a variety of diseases, including cancer. Despite these achievements, gaps are still exist in terms of the how monocyte are derived and what best methods to be used to isolate and culture 
them in vitro, and how to achieve a high yield and purity of the isolated monocytes. As well as appropriate combination of cytokines and growth factors that will generate moDCs and transcription profiles of these cells in different stages of maturation. This review presented key information in relation to the generation of human moDCs from blood monocytes. Furthermore moDCs manufacturing strategies need to be reproducible, robust, and inexpensive with the ultimate goal of providing safe, high-quality products.

\section{FUNDING}

Nil

\section{AUTHORS CONTRIBUTIONS}

All the authors have contributed equally.

\section{CONFLICT OF INTERESTS}

Declared none

\section{REFERENCES}

1. Coley WB. The treatment of malignant tumors by repeated inoculations of erysipelas. With a report of ten original cases. Clin Orthop Relat Res 1991;262:3-11.

2. Yuanyuan Zhang, Zemin Zhang. The history and advances in cancer immunotherapy: understanding the characteristics of tumor-infiltrating immune cells and their therapeutic implications. Cell Mol Immunol 2020;17:807-21.

3. Steinman RM, Cohn ZA. Identification of a novel cell type in peripheral lymphoid organs of mice. I. Morphology, quantitation, tissue distribution. J Exp Med 1973;137:1142-62.

4. Constantino J, Gomes C, Falcao A, Cruz MT, Neves BM. Antitumor dendritic cell-based vaccines: lessons from 20 y of clinical trials and future perspectives. Transl Res 2016;16:74-95.

5. Balan S, Saxena M, Bhardwaj N. Dendritic cell subsets and locations. Int Rev Cell Mol Biol 2019;348:1-68.

6. Gallo PM, Gallucci S. The dendritic cell response to classic, emerging, and homeostatic danger signals. Implications for autoimmunity. Front Immunol 2013;4:138.

7. Pearce EJ, Everts B. Dendritic cell metabolism. Nat Rev Immunol 2015;15:18-29.

8. Hussein Sultan, Juan Wu, Takumi Kumai, Andres M Salazar, Esteban Celis. Role of MDA5 and interferon-I in dendritic cells for $\mathrm{T}$ cell expansion by anti-tumor peptide vaccines in mice. Cancer Immunol Immunother 2018;67:1091-103.

9. Garg AD, Vara Perez M, Schaaf M, Agostinis P, Zitvogel L, Kroemer G, et al. Trial watch: dendritic cell-based anticancer immunotherapy. Oncoimmunology 2017;6:e1328341.

10. Robert 0 Dillman, Andrew N Cornforth, Gabriel I Nistor, Edward F McClay, Thomas T Amatruda, et al. Randomized phase II trial of autologous dendritic cell vaccines versus autologous tumor cell vaccines in metastatic melanoma: 5-year follow up and additional analyses. J Immunother Cancer 2018;6:19.

11. Stefanie K Wculek, Francisco J Cueto, Adriana M Mujal, Ignacio Melero, Matthew F Krummel, David Sancho. Dendritic cells in cancer immunology and immunotherapy. Nat Rev Immunol 2020;20:7-24.

12. Lee AW, Truong T, Bickham K, Fonteneau JF, Larsson M, Da Silva I, et al. A clinical grade cocktail of cytokines and PGE2 results in uniform maturation of human monocyte-derived dendritic cells: implications for immunotherapy. Vaccine 2002;20:8-22.

13. Kantoff PW, Higano CS, Shore ND, Berger ER, Small EJ, Penson DF, et al. Sipuleucel-T immunotherapy for castration-resistant prostate cancer. N Engl J Med 2010;363:411-22.

14. Kumar C, Kohli S, Chiliveru S, Bapsy PP, Jain M, Suresh Attili VS, et al. A retrospective analysis comparing $\operatorname{APCEDEN}(\mathrm{R})$ dendritic cell immunotherapy with best supportive care in refractory cancer. Immunotherapy 2017;9:889-97.

15. Beatris Mastelic Gavillet, Klara Balint, Caroline Boudousquie, Philippe 0 Gannon, Lana E Kandalaft. Personalized dendritic cell vaccines-recent breakthroughs and encouraging clinical results. Front Immunol 2019;10:766.
16. Lisa B Boyette, Camila Macedo, Kevin Hadi, Beth D Elinoff, John $\mathrm{T}$ Walters, Bala Ramaswami, et al. Phenotype, function, and differentiation potential of human monocyte subsets. PLoS One 2017;12:e0176460.

17. Strasser EF, Eckstein. Optimization of leukocyte collection and monocyte isolation for dendritic cell culture. Transfus Med Rev 2010;24:130-9.

18. Smita K Nair, Timothy Driscoll, David Boczkowski, Robert Schmittling, Renee Reynolds, Laura A Johnson, et al. Ex vivo generation of dendritic cells from cryopreserved, postinduction chemotherapy, mobilized leukapheresis from pediatric patients with medulloblastoma. J Neurooncol 2015;125:65-74.

19. Giovana Cechim, Jose $A B$ Chies. In vitro generation of human monocyte-derived dendritic cells methodological aspects in a comprehensive review. An Acad Bras Cienc 2019;91:4.

20. Beatris Mastelic Gavillet, Klara Balint, Caroline Boudousquie, Philippe 0 Gannon, Lana E Kandalaft. Personalized dendritic cell vaccine-recent breakthroughs and encouraging clinical results. Fron Immunol 2019;10:766.

21. Boyum A. Isolation of mononuclear cells and granulocytes from human blood. Scand J Clin Lab Invest 1968;21:77-89.

22. Lara T Meitala, Alexander S Cowarda, Mark T Windsor, Tom G Bailey, Anna Kuballa, Fraser D Russella. A simple and effective method for the isolation and culture of human monocytes from small volumes of peripheral blood. J Immunol Methods 2019;472:75-8.

23. Meyer TP, Zehnter I, Hofmann B, Illert We. Buffy coats (FBC): a source of peripheral blood leukocytes recovered from leukocytedepletion filters. J Immunol Methods 2005;20:150-66.

24. Ito Y, Shinomiya K. A new continuous-flow cell separation method based on cell density: principle, apparatus, and preliminary application to separation of human buffy coat. J Clin Apher 2001;16:186-91.

25. Lehner M, Holter W. Endotoxin-free purification of monocytes for dendritic cell generation via discontinuous density gradient centrifugation based on diluted ficoll-paque plus. Int Arch Allergy Immunol 2002;128:73-6.

26. Wilfried Posch, Cornelia Lass Florl, Doris Wilflingseder. Generation of human monocyte-derived dendritic cells from whole blood. J Vis Exp 2016;118:54968.

27. Delirezh N, Shojaeefar E, Parvinp, Asadi B. Comparison the effects of two monocyte isolation methods, plastic adherence and magnetic activated cell sorting methods, on phagocytic activity of generated dendritic cells. Cell J 2013;15:218-23.

28. Christophe Macri, Ben Fancke, Kristen J Radford, Meredith O'Keeffe. Monitoring dendritic cell activation and maturation. Methods Mol Biol 2019;1988:403-18.

29. Thaize Quiroga Chometon, Mariana da Silva Siqueira, Julie Carmo Sant Anna, Matheus Rogerio Almeida, Mariana Gandini, Ana Cristina Martins de Almeida Nogueira, et al. A protocol for rapid monocyte isolation and generation of singular human monocyte-derived dendritic cells. PLoS One 2020;15:e0231132.

30. Moore GE, Gerner RE, Franklin HA. Culture of normal human leukocytes. JAMA 1967;199:19-524.

31. Gloria Figueroa, Tiyash Parira, Alejandra Laverde, Gianna Casteleiro, Amal El-Mabhouh, Madhavan Nair, et al. Characterization of human monocyte-derived dendritic cells by imaging flow cytometry: a comparison between two monocyte isolation protocols. J Vis Exp 2016;116:54296.

32. Vastsan RS, Bross PF, LIU K, Theoret M, Puri RK. Regulation of immunotherapeutic products for cancer and FDA's role in product development and clinical evaluation. J Immunother Cancer 2013;29:1-5.

33. Deluce Kakwata Nkor N, Lamendour L, Chabot V, Heraud A, Ivanovic Z, Halary F, et al. Differentiation of human dendritic cell subsets for immune tolerance induction. Transfus Clin Biol 2018;25:90-5.

34. Tsing Lee Tang Huau, Elodie Segura. Human in vivodifferentiated monocyte-derived dendritic cells. Semin Cell Dev Biol 2019;86:44-9. 
35. Obermaier B, Dauer M, Herten J, Eigler A. Development of a new protocol for 2-day generation of mature dendritic cells from human monocytes. Biol Proced Online 2003;5:197-203.

36. Sallusto F, Lanzavecchia A. Efficient presentation of soluble antigen by cultured human dendritic cells is maintained by granulocyte/macrophage colony-stimulating factor plus interleukin-4 and down regulated by tumor necrosis factor alpha. J Exp Med 1994;179:1109-18.

37. Suzuki H. Activities of granulocyte-macrophage colonystimulating factor and interleukin-3 on monocytes. Am J Hematol 2004;75:179-89.

38. Jansen JH, Wientjens GJ, Fibbe WE, Willemze R, Kluin HC. Inhibition of human macrophage colony formation by interleukin-4. J Exp Med 1989;170:577-82.

39. Relloso M, Puig Kroger A, Fello OM, De La Rosa, Corbi AL. DCSIGN (CD209) expression is IL-4 dependent and is negatively regulated by IFN, TGF-beta, and anti-inflammatory agents. J Immunol 2002;168:2634-43.

40. Sanarico N, Ciaramella A, Sacchi A, Vendetti. Human monocytederived dendritic cells differentiated in the presence of IL-2 produce proinflammatory cytokines and prime Th1 immune response. J Leukoc Biol 2006;80:555-62.

41. Takahashi K, Honeyman MC, Harrison. Dendritic cells generated from human blood in granulocyte macrophagecolony stimulating factor and interleukin-7. Hum Immunol 1997;55:103-16.

42. Santini SM, Lapenta C, Logozzi M, Parlato S, Belardelli F. Type I interferon as a powerful adjuvant for monocyte-derived dendritic cell development and activity in vitro and in $\mathrm{Hu}-\mathrm{PBL}-$ SCID mice. J Exp Med 2000;191:1777-88.

43. Mohty M, Vialle Castellano A, Nunes JA, Isnardon D, Olive D, Gaugler B. IFN-alpha skews monocyte differentiation into Toll-like receptor 7-expressing dendritic cells with potent functional activities. J Immunol 2003;171:3385-93.

44. Iwamoto S, Iwai S, Tsujyama K, Kirashashi C, Miyazaki A. TNFalpha drives human CD14+monocytes to differentiate into CD70+dendritic cells evoking Th1 and Th17 responses. J Immunol 2007;179:1449-57.

45. Patrick Han, Douglas Hanlon, Olga Sobolev, Rabib Chaudhury, Richard L Edelson. Ex vivo dendritic cell generation-a critical comparison of current approaches. Int Rev Cell Mol Biol 2019;349:251-307.

46. Francesca Fallarino, Maria T Pallotta, Davide Matino, Marco Gargaro, Ciriana Orabona, Carmine Vacca, et al. LPSconditioned dendritic cells confer endotoxin tolerance contingent on tryptophan catabolism. Immunobiology 2015;220:315-21.

47. Marita Chakhtoura, Uma Sriram, Michelle Heayn, Joshua Wonsidler, Christopher Doyle, Joudy-Ann Dinnall. Bisphenol a does not mimic estrogen in the promotion of the in vitro response of murine dendritic cells to toll-like receptor ligands. Mediators Inflamm 2017;2017:2034348.

48. Vicente Suarez I, Brayer J, Villagra A, Cheng F, Sotomayor EM. TLR5 ligation by flagellin converts tolerogenic dendritic cells into activating antigen-presenting cells that preferentially induce T-helper 1 responses. Immunol Lett 2009;125:114-8.

49. Coffman RL, Sher A, Seder RA. Vaccine adjuvants: putting innate immunity to work. Immunity 2010;33:492-503.

50. Hemmi H. A toll-like receptor recognizes bacterial DNA. Nature 2000;408:740-5.

51. Jenny Bulgarelli, Laura Fiammenghi, Serena Cassan, Anna Maria Granato, Massimiliano Petrini, Elena Pancisi, et al. Skewing effect of sulprostone on dendritic cell maturation compared with dinoprostone. Cytotherapy 2018;20:851-60.

52. Nazarkina Zh K, Zajakina A, Laktionov PP. Maturation and antigen loading protocols influence activity of anticancer dendritic cells. Mol Biol Mosk 2018;52:257-69.

53. Brencicova E, Jagger AL, Evans HG, Georgouli M, Laios A, Attard Montalto S, et al. Interleukin-10 and prostaglandin E2 have complementary but distinct suppressive effects on toll-like receptor-mediated dendritic cell activation in ovarian carcinoma. PLoS One 2017;12:e0175712.

54. Trabanelli S, Lecciso M, Salvestrini V, Cavo M, Ocadlikova D, Lemoli RM, et al. PGE2-induced ID01 inhibits the capacity of fully mature DCs to elicit an in vitro antileukemic immune response. J Immunol Res 2015. DOI:10.1155/2015/253191

55. Jenny Sprooten, Patrizia Agostinis, Abhishek D Garg. Type I interferons and dendritic cells in cancer immunotherapy. Int Rev Cell Mol Biol 2019;348:217-62.

56. Bol KF, Aarntzen EH, Pots JM, Olde Nordkamp MA, van de Rakt MW, Scharenborg NM, et al. Prophylactic vaccines are potent activators of monocyte-derived dendritic cells and drive effective anti-tumor responses in melanoma patients at the cost of toxicity. Cancer Immunol Immunother 2016;65:327-39.

57. Motao Zhu, Xilai Ding, Ruifang Zhao, Xuewu Liu, Haifa Shen, Chunmei Cai, et al. Co-delivery of tumor antigen and dual tolllike receptor ligands into dendritic cell by silicon microparticle enables efficient immunotherapy against melanoma. J Controlled Release 2018;272:72-82.

58. Brabants E, Heyns K, Smet S De, Devreker P, Ingels J, Cabooter $\mathrm{N}$ De, et al. An accelerated, clinical-grade protocol to generate high yields of type 1-polarizing messenger RNA-loaded dendritic cells for cancer vaccination. Cytotherapy 2018;20:1164-81.

59. Caux C, Dezutter DC, Schmitt D, Banchereau J. GM-CSF and TNFalpha cooperate in the generation of dendritic langerhans cells. Nature 1992;360;258-61.

60. Olga Yu Leplina, Tamara V Tyrinova, Marina A Tikhonova, Alexander A Ostanin, Elena R Chernykh. Interferon alpha induces generation of semi-mature dendritic cells with high pro-inflammatory and cytotoxic potential. Cytokine 2015;71:1-7.

61. Xuemin Jin, Yong Yang, Xiaolei Liu, Haining Shi, Xuepeng Cai, Xuenong Luo, et al. Glutathione-S-transferase of trichinella spiralis regulates maturation and function of dendritic cells. Parasitology 2019;146:1725-32.

62. Xi Chen, Qianqian Shao, Shengnan Hao, Zhonghua Zhao, Yang Wang, Xiaofan Guo, et al. CTLA-4 positive breast cancer cells suppress dendritic cells maturation and function. Oncotarget 2017;8:13703-15.

63. Anna M Schulz, Susanne Stutte, Sebastian Hogl, Nancy Luckashenak, Diana Dudziak, Celine Leroy, et al. Cdc42dependent actin dynamics controls maturation and secretory activity of dendritic cells. J Cell Biol 2015;211:553-67.

64. Valerie Chabot, Laurence Martin, Daniel Meley, Luc Sensebe, Christophe Baron, Yvon Lebranchu, et al. Unexpected impairment of TNF- $\alpha$-induced maturation of human dendritic cells in vitro by IL-4. J Transl Med 2016;14:93.

65. Farhan Basit, Till Mathan, David Sancho, I Jolanda M de Vries. Human dendritic cell subsets undergo distinct metabolic reprogramming for immune response. Front Immunol 2018;9:2489.

66. Maria Gschwandtner, Philip Kienzl, Poojabahen Tajpara, Christopher Schuster, Gernot Stipek, Maria Buchberger, et al. The reticulum-associated protein RTN1A specifically identifies human dendritic cells. J Invest Dermatol 2018;138:1318-27.

67. Moignic A Le, Malard V, Benvegnu T, Lemiègre L, Berchel $M$, Jaffrès PA, et al. Preclinical evaluation of mRNA trimannosylated lipopolyplexes as therapeutic cancer vaccines targeting dendritic cells. J Controlled Release 2018;278:110-21.

68. Schreiber RD, Old LJ, Smyth MJ. Cancer immunoediting: integrating immunity's roles in cancer suppression and promotion. Science 2011;331:1565-70.

69. Zou W. Immunosuppressive networks in the tumour environment and their therapeutic relevance. Nat Rev Cancer 2005;5:263-74.

70. Burnet FM. The concept of immunological surveillance. Prog Exp Tumor Res 1970;13:1-27.

71. Muul LM, Spiess PJ, Director EP, Rosenberg SA. Identification of specific cytolytic immune responses against autologous tumor in humans bearing malignant melanoma. J Immunol 1987;138:989-95.

72. Robert A Belderbos, Joachim G J V Aerts, Heleen Vroman. Enhancing dendritic cell therapy in solid tumors with immunomodulating conventional treatment. Mol Ther Oncolytics 2019;13:67-81.

73. Veronica Rainone, Cristina Martelli, Luisa Ottobrini, Mara Biasin, Gemma Texido, Anna Degrassi, et al. Immunological 
characterization of whole tumour lysate-loaded dendritic cells for cancer immunotherapy. PLoS One 2016;11:e0146622.

74. Madiha Derouazi, Wilma Di Berardino-Besson, Elodie Belnoue, Sabine Hoepner, Romy Walther, Mahdia Benkhoucha, et al. Novel cell-penetrating peptide-based vaccine induces robust CD4+and CD8+T cell-mediated antitumor immunity. Cancer Res 2015;75:3020-31.

75. Hirooka Y, Kawashima H, Ohno E, Ishikawa T, Kamigaki T, Goto $\mathrm{S}$, et al. Comprehensive immunotherapy combined with intratumoral injection of zoledronate-pulsed dendritic cells, intravenous adoptive activated T lymphocyte and gemcitabine in unresectable locally advanced pancreatic carcinoma: a phase I/II trial. Oncotarget 2018;9:2838-47.

76. Lee JM, Lee MH, Garon E, Goldman JW, Salehi Rad R, Baratelli $\mathrm{FE}$, et al. Phase I trial of intratumoral injection of CCL21 genemodified dendritic cells in lung cancer elicits tumor-specific immune responses and CD8+T-cell infiltration. Clin Cancer Res 2017;23:4556-68.

77. Katja Fiedler, Sandra Lazzaro, Johannes Lutz, Susanne Rauch, Regina Heidenreich. mRNA Cancer vaccines. Recent Results Cancer Res 2016;209:61-85.

78. Hsu FJ, Benike C, Fagnoni F, Liles TM, Czerwinski D, Taidi B, et al. Vaccination of patients with B-cell lymphoma using autologous antigen-pulsed dendritic cells. Nat Med 1996;2:52-8.

79. Ahmed MS, Bae YS. Dendritic cell-based therapeutic cancer vaccines, past, present and future. Clin Exp Vaccine Res 2014;3:113-6.

80. Constantino J, Gomes C, Falcao A, Neves BM, Cruz MT. Dendritic cell-based immunotherapy: a basic review and recent advances: Immunol Res 2017;65:798-810.

81. Bol KF, Schreibelt G, Gerritsen WR, de Vries IJM, Figdor CG. Dendritic cell-based immunotherapy: state of the art and beyond. Clin Cancer Res 2016;22:1897-906.

82. Shortman K, Naik SH. Steady-state and inflammatory dendriticcell development. Nat Rev Immunol 2007;7:19-30.

83. Patricia M Santos, Lisa H Butterfield. Dendritic cell-based cancer vaccines. J Immunol 2018;200:443-9.

84. Fong L, Engleman EG. Dendritic cells in cancer immunotherapy. Annu Rev Immunol 2000;18:245-73.

85. Wei Li, Xiujun Song, Huijie Yu, Manze Zhang, Fengsheng Li, Cheng Cao, et al. Dendritic cell-based cancer immunotherapy for pancreatic cancer. Arab J Gastroenterol 2018;19:1-6.

86. Ludewig B, Oehen S, Barchiesi F, Schwendener RA, Hengartner H, Zinkernagel RM. Protective antiviral cytotoxic T cell memory is most efficiently maintained by restimulation via dendritic cells. J Immunol 1999;163:1839-44.

87. Guery JC, Ria F, Adorini L. Dendritic cells but not B cells present antigenic complexes to class II-restricted $T$ cells after administration of protein in adjuvant. J Exp Med 1996;183:751-7.

88. Mehta Damani A, Markowicz S, Engleman EG. Generation of antigen-specific CD8+CTLs from naive precursors. J Immunol 1994;153:996-1003.

89. Mehta Damani A, Markowicz S, Engleman EG. Generation of antigen-specific CD4+T cell lines from naive precursors. Eur J Immunol 1995;25:1206-11.

90. Celluzzi CM, Mayordomo JI, Storkus WJ, Lotze MT, Falo LD. Jr peptide-pulsed dendritic cells induce antigen-specific CTLmediated protective tumor immunity. J Exp Med 1996;183:283-7.

91. Paglia P, Chiodoni C, Rodolfo M, Colombo MP. Murine dendritic cells loaded in vitro with soluble protein prime cytotoxic $\mathrm{T}$ lymphocytes against tumor antigen in vivo. J Exp Med 1996;183:317-22.

92. Stefanie K Wculek, Joaquin Amores Iniesta, Ruth Conde Garrosa, Sofía C Khouili, Ignacio Melero, David Sancho. Effective cancer immunotherapy by natural mouse conventional type-1 dendritic cells bearing dead tumor antigen. J Immunother Cancer 2019;7:100.

93. Dhodapkar MV, Steinman RM, Sapp M, Desai H, Fossella C, Krasovsky J, et al. Rapid generation of broad T-cell immunity in humans after a single injection of mature dendritic cells. J Clin Invest 1999;104:173-80.

94. Schuler Thurner B, Dieckmann D, Keikavoussi P, Bender A, Maczek $\mathrm{C}$, Jonuleit $\mathrm{H}$, et al. Mage-3 and influenza-matrix peptide-specific cytotoxic $\mathrm{T}$ cells are inducible in terminal stage HLA-A2.1+melanoma patients by mature monocytederived dendritic cells. J Immunol 2000;165:3492-6.

95. Randolph GJ, Inaba K, Robbiani DF, Steinman RM, Muller WA. Differentiation of phagocytic monocytes into lymph node dendritic cells in vivo. Immunity 1999;11:753-61.

96. Randolph GJ, Beaulieu S, Lebecque S, Steinman RM, Muller WA Differentiation of monocytes into dendritic cells in a model of transendothelial trafficking. Science 1998;282:480-3.

97. Albert ML, Jegathesan M, Darnell RB. Dendritic cell maturation is required for the cross-tolerization of CD8+T cells. Nat Immunol 2001;2:1010-7.

98. Hitoshi Hasegawa, Image Takuya Matsumoto. Mechanisms of tolerance Induction by dendritic cells in vivo. Front Immunol 2018;9:350. 